"Factors affecting youth entrepreneurship development in Kibera district, Kenya" AUTHORS Wise Sambo

ARTICLE INFO

Wise Sambo (2016). Factors affecting youth entrepreneurship development in Kibera district, Kenya. Problems and Perspectives in Management, 14(3-1), 154161. doi:10.21511/ppm.14(3-1).2016.02

DOI http://dx.doi.org/10.21511/ppm.14(3-1).2016.02

RELEASED ON Tuesday, 06 September 2016

JOURNAL "Problems and Perspectives in Management"

FOUNDER LLC "Consulting Publishing Company "Business Perspectives"

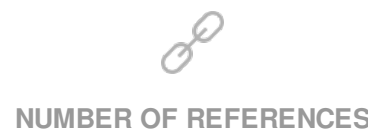

0

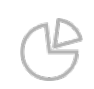

NUMBER OF FIGURES

0

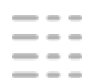

NUMBER OF TABLES

0

(C) The author(s) 2023. This publication is an open access article. 
Wise Sambo (South Africa)

\title{
Factors affecting youth entrepreneurship development in Kibera district, Kenya
}

\begin{abstract}
Entrepreneurship and business creation are a growing alternative for young people in different economies whose age group often faces a labor market with double digit unemployment rates. Due to low economic growth, traditional career paths and opportunities are disappearing rapidly. In response to these challenges, the government introduced the National Youth Policy (NYP), amongst others, to deal with the challenges facing youth in Kenya. It was through the NYP that the Youth Enterprise Development Fund (YEDF) was transformed to a state corporation in 2007 as a strategic move toward arresting unemployment among youth in Kenya. This study sought to report on the factors affecting youth entrepreneurship development in Kibera, a district of Kenya. Kibera is a low income, informal settlement in southwest Nairobi (Kenya) with an estimated population of one million housed on less than $2 \%$ of the total municipal residential land (or 3,000 people per hectare). A sample of three hundred entrepreneurs (aged 18-35) within the Kibera district, Kenya was drawn to participate in this study. Structured survey questionnaires were used to collect data from young business owners in Kibera. Findings revealed that government policy (NYP) and access to credit have a moderate to strong positive relationship in the development of youth entrepreneurship. Though the positive relationship shows that the Kenyan government is supporting youth entrepreneurship in Kibera, there have been differing views as to whether the programs to support youth are yielding positive results or not.
\end{abstract}

Keywords: youth entrepreneurship, Kenya national youth policy, unemployment, Kibera.

JEL Classification: L26, E24.

\section{Introduction}

Kenya's vision of becoming a middle income economy (industrialized) by the year 2030 largely depends on the emancipation and active participation of youth in the economic development of the country. Since independence, the role of youth in Kenya has been largely peripheral leading to their current marginalization manifested in the form of unemployment, crime, drug abuse and passive involvement in constructive nation building (Rori, Bunei \& Mwenzwa, 2011). Like any other developing nation, entrepreneurship and self-employment in Kenya can be a source of new jobs and economic dynamism and can improve youth livelihoods and economic independence of inhabitants. For young people in the informal economy, microentrepreneurism is a bottom-up method for generating income, self-reliance and a new innovative path to earning a living and caring for oneself (Maxwell, 2002). A growing number of young people are taking up the challenge of starting their own businesses in Kenya and much is being learned about how the odds for success can be improved through various types of assistance and through the creation of a conducive environment (Schoof, 2006). Of late, entrepreneurship development in Kenya is primarily aimed at youth in technical training institutions and is now being expanded to include the universities. This program involves introducing youth to SME startup programs with the aim of getting them to think about self-

(C) Wise Sambo, 2016

Wise Sambo, M.Tech., Economic and Management Sciences, Department of Business Management, University of South Africa, South Africa. employment after graduation. They also get an opportunity to analyze the difficult employment situation in Kenya and are encouraged to consider selfemployment as a career choice (Kaburi, Mobegi, Kombo, Omari \& Sewe, 2012). Thus, this study analyzed the national youth policy and access to credit to see if these two variables assist in the development of youth entrepreneurs in Kibera.

\section{Research problem statement}

As Kenya remains focused to achieve its Vision 2030, the youths in Kenya are faced with challenges, particularly in the economic context of livelihoods (Omondi, 2013). A large population of young people are without work and many more are engaged in short-term, low-paid jobs or in the informal economy. The youth represent $43 \%$ of the working age population in Kenya and constitute $70 \%$ of total unemployment (Kilele, 2008). Decent work can also shift young people from social dependence to selfsufficiency and escape from poverty. In the absence of decent work opportunities, entrepreneurship provides the best alternative to youth in accessing decent work and creation of more job opportunities for others. Despite this universally agreed fact, the rate of young Kenyans starting successful enterprises is minimal. Poor economic participation of young people inhibits the country's economic development and imposes a larger burden due to high dependency on the working population. This study intended to investigate the factors affecting youth entrepreneurship development in Kenya with specific reference to the national youth policy and access to credit. 


\section{Research objectives}

- To determine the extent to which the national youth policy assists in the development of youth entrepreneurship in Kibera.

- To determine whether there is a correlation between access to credit and the development of youth enterprises in Kibera.

\section{Literature review}

3.1. The concept of youth and entrepreneurship. Youthhood is viewed as a specific stage between childhood and adulthood when people have to negotiate a complex interplay of both personal and socio-economic changes in order to maneuver the "transition" from dependence to being independent, take effective control of their own lives and assume social commitments (UNESCO, 2010). In a study by Chingunta, Schnurr \& James-Wilson (2005), the United Nations (UN) and the Commonwealth of Nations have, respectively, defined youth as those members of the population between 15-24 and 15-29 years of age. While the Africa Youth Charter by the African Union (2006) (in Chigunta et al., 2005) has defined youth as that category of people between ages 15 and 35 years, it is only those individuals who are 18 years old and above under Kenyan law who can be permitted to enter into legal contracts. This definition takes into account the physical, psychological, cultural, social, biological and political aspects, which explain the Kenyan youth situation. For the purpose of this study, a definition above by the African Union (2006) was adopted. Since it was indicated that individuals younger than 18 have no contractual capacity, the study followed the lower end age of 18, meaning youth are individuals of 18-35 years old. According to Chigunta et al. (2005), youth entrepreneurship is the practical application of enterprising qualities, such as initiative, innovation, creativity, and risk-taking into the work environment (either in self-employment or employment in small start-up firms), using the appropriate skills necessary for success in that environment and culture by individuals within the youth age group bracket.

\subsection{Government efforts through policy} intervention. In Kenya, approximately 500,000 graduates from various tertiary academic institutions entered the job market annually (Murimi, 2014). Murimi (2014) further explains that it is due to low economic growth, rampant corruption, nepotism and demand for experience by potential employees, that the majority of youth remain unemployed in Kenya. To address youth problems and more specifically unemployment and empowerment, efforts have been made by the Government to initiate youth development programs through policy documents such as: Sessional Paper Number 4 of 2005, Sessional Paper Number 2 of 1992 on Small Scale and Jua Kali
Enterprises, Development Plan 1997-2001, and the Poverty Eradication Plan 1999-2015, among others (Okirigiti, 2015), and more importantly the sessional paper no 3 of 2007 (National Youth Policy (NYP)) among others (Okirigiti, 2015). The NYP is aimed at ensuring that youth play their role, alongside adults, in the development of the country. The policy's goal is to promote youth participation in community and civic affairs and to ensure that youth programs are youth centred (Kenya National Youth Policy, 2007). Furthermore, the NYP has identified strategic areas including employment creation, health, education and training, sports and recreation, the environment, art and culture, the media and participation and empowerment. The policy also recognizes the unique needs of certain groups of youth such as female youth, youth with disability, street youth, youth infected with HIV/AIDS, unemployed youth and out of school youth (Muthee, 2010). The NYP proposed guidelines and strategies to facilitate the engagement of the youth in national development and provides broad-based strategies that can be used to give the youth meaningful opportunities to reach their maximum potential. It also provides a framework within which all stakeholders, including the private and public sector and civil society, can contribute to youth.

In addition to the efforts above, the Youth Enterprise Development Fund (YEDF) was conceived by the government in June 2006 as a strategic move towards arresting unemployment among the youth in Kenya (Kanyari \& Namusonge, 2013). This fund was established to achieve the following objectives: to provide loans to existing micro-finance institutions (MFIs), registered non-governmental organizations (NGOs) involved in micro-financing, and savings and credit co-operative organizations (SACCOS) for lending to youth enterprises; to attract and facilitate investment in micro, small and medium enterprises, oriented commercial infrastructure such as business or industrial parks, and markets or business incubators that will be beneficial to youth enterprises; to support youth-oriented micro, small and medium enterprises to develop linkages with large enterprises; to facilitate marketing of products and services of youth enterprises in both domestic and international markets; to facilitate employment of youth in the international labor market (Gachugia, Mulu-Mutuku \& Odero-Waga, 2014).

The NYP has been integrated into many spheres of government, as it is believed that a single stakeholder cannot carry out youth development in the whole Kenya (National Youth Policy, 2007). However, there is little systematic knowledge about the effectiveness of the programs brought by the NYP in terms of increasing entrepreneurial attitudes among school and university youth and about the likelihood that 
education leavers would venture into a business career (Franz, 2014). A different study by Musera (2015) found that there is a relationship between the financial support services and the success of youth enterprises and the same study could not conclude as to whether there is a relationship between government policy and the success of youth enterprises. As indicated earlier in the study, entrepreneurship development in Kenya is recently aimed at youth at technical training institutions and it is further extended to include the universities (Kaburi et al., 2012).

3.3. Youth entrepreneurship development in Kenya. The population growth rate in Kenya has outstripped both economic growth and job opportunities (Sagwe, Gicharu \& Mahea, 2011). Nonetheless, entrepreneurship has been proven to be beneficial for economic growth, job creation and poverty alleviation (Chiloane-Tsoka \& Mmako, 2014). In South Africa, government sponsored initiatives targeted at supporting youth entrepreneurs financially or otherwise include institutions such as the National Youth Development Agency (NYDA) (Youth Business International, 2011). In Kenya, various programs by the government such as youth and women enterprise development fund have been put in place through the policy documents highlighted earlier in the study to facilitate the creation of entrepreneurial ventures (Sagwe, Gicharu \& Mahea, 2011).

The Ministry of State for Youth Affairs in partnership with various private financial intermediaries is administering the Youth Enterprise Development Fund to the youth (Office of the President and Ministry of State for Youth Affairs, 2007). This fund has been specifically tailored to enhance the youth development programs with specific focus on selfemployment via entrepreneurship initiatives. Youth can access these funds either as individuals or as groups and the collateral to secure the money borrowed has been made affordable in the sense that they can be in form of group guarantee, guarantee by parents, relatives or and even community leaders. However, these initiatives are not without challenges, as unemployment among youth remains high in Kenya (Okirigiti \& Rafey, 2015). Okirigiti and Rafey (2015) further alluded that it is unemployment that drives young people into crime and drugs, and into a general state of hopelessness and despair.

3.4. Barriers that hinder youth entrepreneurship development in Kenya. This study uses the term challenge interchangeably with "barriers" throughout the paper depending on how different authors have reported their research in the literature. The challenges facing youth in Kenya were best summarized in a stakeholder workshop on youth and development organized by the World Bank in March 11 2004, and recorded a number of risk factors affecting youth in
Kenya (cited in Kaburi et al., 2012). The workshop had 29 participants from youth organizations, World Bank, United Nations and the Government. Below are some of the potential barriers identified that affect entrepreneurship development in Kenya.

3.5. Education. Governments around the world have shown a growing interest in interventions that promote entrepreneurial success, making significant investments in entrepreneurship education and training (EET) (Valerio, Parton \& Robb, 2014). Although primary education is free for all Kenyans, there is a limited access to secondary schools, and alternative forms of education are lacking in Kibera and the rest of Kenya. Furthermore, there is a need for life skills training in the education curriculum. At present, students are trained just to pass exams (Kaburi et al., 2012).

3.6. Society's attitude towards youth. According to the African Economic Outlook (2016), one of the most powerful of these barriers to employment opportunities for many young people is discrimination (i.e., negative attitudes towards inexperienced young workers). According to Kaburi et al. (2012), this is legitimatized by beliefs such as wisdom only comes with age, and that youth is merely a transition period. Society also perceives youth as irresponsible and troublemakers and this perception may contribute to difficulty in obtaining credit. Chitukutuku (2014) argues that young people face constant pressure from elders and peers to possess and to be possessed.

3.7. Expectations of youth. It is important to note that what the youth of today consider important and valuable is access to employment opportunities (Chitukutuku, 2014). In Kenya, society's expectations of young people are not very clear (Kaburi et al., 2012). According to Kenya Voluntary Development Association (KVDA) (2015), a gap in expectations has opened between what parents and older generations expect of youth, on the one hand, and the expectations of youth themselves (influenced by their peers, and the media, etc.). Furthermore, society's expectations of youth may overshadow personal expectations and overwhelm youth (KVDA, 2015). There is also an assumption that white-collar jobs are best and little encouragement is offered to youth to take up bluecollar jobs (Kimando \& Njogu, 2012).

3.8. Access to credit. According to Kamau, Wanyoike and Mwangi (2014), access and availability of affordable credit ensure that youth entrepreneurs can benefit from the credit facilities to start and expand their enterprises and also take advantage of emerging opportunities. However, accessing credit is a major constraint to the development and growth of small and micro enterprises (SMEs) and also to poor rural and urban households (Mwangi \& Shem, 2012). Studies 
conducted in Africa also supported the contention that lack of finance was a major challenge for young aspirant entrepreneurs. A study carried out in Zambia found that the majority of youth entrepreneurs cited lack of capital as the major reason as to why they were not self-employed (Chigunta et al., 2005). Ayodele in Maina (2012) found inadequate capital to be one of the principal factors constraining entrepreneurship in Nigeria. Clearly access to finance for young aspirant entrepreneurs is a global challenge and Kenya is no exception. Traditional financial institutions have avoided lending to youth due to their relative inability to comply with the high transaction costs, difficulty in assessing and managing their risk profile, and lack of the required financial documentation, as well as collateral (Moraa New Hope Foundation, 2015).

\section{Research hypotheses}

In order to address the above mentioned research objectives, the data sampled were used to quantitatively test the following hypotheses:

1. $H_{0}$ (null hypothesis): There is no relationship between the national youth policy and the development of youth entrepreneurship.

$H_{1}$ (alternate hypothesis): There is a relationship between the national youth policy and the development of youth entrepreneurship.

2. $H_{0}$ (null hypothesis): There is no relationship between access to credit and youth entrepreneurship development.

$H_{1}$ (alternate hypothesis): There is a relationship between access to credit and development of youth enterprises.

\section{Research methodology}

A quantitative, non-experimental, descriptive research approach was followed in this study. The population comprises all members of the registered youth groups in Kenya. According to the Ministry of Youth Affairs, there were five hundred registered youth groups in Kenya in the year 2012 and twenty five were based in Kibera district. Kibera is a low income, informal settlement in southwest Nairobi, Kenya. With an estimated population of one million housed on less than $2 \%$ of the total municipal residential land (or 3,000 people per hectare), it holds one of the highest population densities in subSaharan Africa (Crosson, 2005).

5.1. Sample selection and size. In this study, a simple random sampling technique was used to select the groups from which the respondents were drawn. The list of registered youth groups as obtained from the Ministry of Youth Affairs was used as the sample frame. Similarly, respondents were identified from the sampled youth groups by simple random sampling. For the purpose of this study, a sample size of three hundred (300) members (respondents) was drawn from twenty five youth groups in the Kibera district and only two hundred and fifty (250) were returned fully completed giving the response rate of $83.3 \%$. Though the ministry did not have records of how many members each group represents, the researcher deemed the sample size to be big enough to report on. According to Mugenda (2003), a sample size that has more than five percent of the population, with at least thirty respondents is considered a large sample, and, in this case, the sample of 300 was considered large enough as is more than thirty respondents.

5.2. Data collection. A questionnaire was used as the instrument for collecting data and consisted of two sections, namely: Section A which covered demographics and business information, while Section B consists of questions that addressed the factors affecting youth entrepreneurship in Kibera. In order to pre-test the data collection instrument, a pilot study was carried out with eight students doing B Com Entrepreneurship at the University of South Africa. The aim of the pilot survey was to determine the scientific correctness of the questionnaires, to note statements that needed clarifications and to establish how long the questionnaires will take to complete. The variables in the questionnaires were mainly based on the themes in the research objectives. In instances where filling of the questionnaire encountered difficulties, the researcher adopted interviews. Prior to completing the questionnaires, respondents were provided with informed consents to complete in order to ensure that the respondents understand their right in that participation was voluntary. Once the respondents accepted the informed consent, they gained full access to the questionnaires. Where an interview was used, the questionnaire formed the basis of the questions asked. In this case, six (6) of the questionnaires that were outstanding had to be completed face-to-face through this interview method at the respondents' premises to fast track the completion of data collection process.

In quantitative research, the survey approach allows for a large collection of data and can be administered face-to-face, by telephone or mail. Mail administered surveys have a wide reach, are relatively cheap to administer, information is standardized and privacy can be maintained. Therefore, the questionnaires were sent to respondents via e-mails and eighteen (18) of them were physically collected by the fieldworker who is based in Kibera.

5.3. Data analysis. This began with pre-processing of collected data through editing to detect errors and omissions and making of corrections. The researcher undertook careful analysis of the completed questionnaires for completeness, accuracy and consistency with the other information gathered. 
Descriptive statistics was used to test the null hypothesis and the collected information was coded and computed using OriginPro 9.1. Furthermore, a regression analysis was used looking at the correlation between the variables in the study.

\section{Results and discussions}

The statistical procedure used to test the hypotheses of the study was the Pearson's correlation coefficient. The following hypotheses (null) below were tested in this study:

$H_{0}$ (null hypothesis): There is no relationship between government policy and the development of youth entrepreneurship.

$H_{1}$ (null hypothesis): There is no relationship between access to credit and development of youth enterprises.

6.1. Demographics of the sampled youth entrepreneurs' in Kibera. There was an equal distribution of gender in business enterprises that were sampled. This shows that youths in Kibera, both male and female, have equal opportunities when it comes to entrepreneurship activities. In terms of age, most of the youths running business enterprises in Kibera were towards the upper end of youth age which is between 26-29 years of age and constituted 60\%. Only a few tend to start businesses at the age of 18-21 years with only $3 \%$, but this number seems to grow drastically when they reach the age of 26-29 years and exponentially when they are in the 30-35 years age group with $37 \%$ for this group. With regard to education, all the target group members indicated they had formal education. This is supported by the large number of primary and secondary schools in the region together with government provision of "Free Primary Education". Most of the youths (50\%) indicated that they have reached diploma level, 30\% only completed high school, $13.3 \%$ had certificates and $6.7 \%$ had postgraduate qualifications.

6.2. Type of business operations. Most of the businesses can be scaled as small scale businesses that have a potential to grow. Interaction with most respondents pointed out that they do not have adequate capital to start or grow their businesses to a middle level business enterprise. It was also noted that more women than men operated groceries. Almost equal number of the two genders operated salons and barber shops. A total of $95 \%$ of all car wash and garages were operated by men. Other business enterprises noted in this research included kiosks, boutiques, butcheries and supermarkets.

6.3. Length of business operation. It was noted that most of the business started have not yet lasted for two years. This indicates that most of the businesses started do not last for a long period. It is perceived that this high rate of business failures is due to youths expecting very high returns in a short duration. Other reasons perceived for this high failure rate include the low level of education (Herrington, Kew, Simrie \& Turton, 2011), government policies, provision and access to entrepreneurship education (Herrington, Kew $\&$ Kew, 2010). It was also noted that, as time goes by, the chances of sustaining a business in Kibera also decline. Very few businesses that were started by the youths in Kibera have lasted for 7 to 9 years.

6.4. Hypotheses testing. In order to determine how government policy (NYP) and access to credit affect youth entrepreneurship development, Pearson's product moment correlation was computed using OriginPro 9.1. Similar results were obtained when Microsoft Excel 2013 was used.

6.4.1. Hypothesis one. $H_{0}$ (null hypothesis): There is no relationship between National Youth Policy (NYP) and the development of youth entrepreneurship.

In relation to this hypothesis, Franz (2014) reported that there is little systematic knowledge about the effectiveness of the programs brought through the National Youth Policy in terms of increasing the entrepreneurial attitudes of youth to venture into business.

In order to test this hypothesis, frequencies of Youth Entrepreneurial Development (X) and the National Youth Policy (Y) were tabulated from the data collection form. Table 1 summarizes the results obtained in finding the correlation coefficient of these variables using two-tailed test for significance.

Table 1. Correlation between youth entrepreneurship development and National Youth Policy (NYP)

\begin{tabular}{|l|l|c|c|c|c|c|}
\hline \multicolumn{1}{|c|}{ Descriptive statistics } & \multicolumn{1}{c|}{ N } & Mean & SD & Sum & Min & Max \\
\hline NYP & \multicolumn{1}{|c|}{30} & 2.87667 & 0.86211 & 86.3 & 1 & 4 \\
\hline Youth entrepreneurship & 30 & 3.03333 & 0.56283 & 91 & 2 & 4 \\
\hline Pearson's correlation & & & & & & \\
\hline & & NYP & \multicolumn{2}{|c|}{ Youth entrepreneurship } & \\
\hline NYP & Pearson's corr. & 1 & 0.53323 & & & \\
\hline NYP & Sig. & -- & 0.00241 & & & \\
\hline Youth entrepreneurship & Pearson's corr. & 0.53323 & 1 & & & \\
\hline Youth entrepreneurship & Sig. & 0.00241 & -- & & & \\
\hline
\end{tabular}


The correlation coefficient obtained was 0.5 showing a moderate positive correlation between the national youth policy and development of youth entrepreneurship. At 0.05 , the significant value was 0.00241 . The study, therefore, rejects the null hypothesis (there is an overwhelming evidence of relationship) and accepts the alternate hypothesis. There is every reason to believe that relationship exist between Youth Entrepreneurial Development and the national youth policy, as we are 95\% confident that this relationship exists.

6.4.2. Hypothesis two. $H_{0}$ (null hypothesis): There is no relationship between access to credit and the development of youth enterprises.
One of the main barriers for youth entrepreneurs is the lack of access to financing and lack of credit history which makes it difficult to access mainstream products like bank and equity finance (Llisterri et al., 2006). According to Mureithi (2010), youth do not have access to information on the services and support systems available to assist them become entrepreneurs. This may be generic or specifically targeted to youth. They lack social capital and networks that adults may have accumulated over time. In order to affirm this claim, frequencies of Youth Entrepreneurial Development $(\mathrm{X})$ and Access to Credit (Y) were tabulated from the data collection form. Table 3 summarizes results obtained in finding the correlation coefficient of these variables.

Table 2. Correlation between Youth Entrepreneurial Development and access to credit

\begin{tabular}{|l|l|c|c|c|c|c|}
\hline \multicolumn{1}{|c|}{ Descriptive statistics } & \multicolumn{1}{c|}{ N } & Mean & SD & Sum & Min & Max \\
\hline Access to credit & 30 & 2.85 & 0.96401 & 85.5 & 1 & 4 \\
\hline Youth entrepreneurship & 30 & 3.03333 & 0.56283 & 91 & 2 & 4 \\
\hline Pearson's correlation & & & & & \\
\hline & & & & & \\
\hline Access to credit & & Access to credit & Youth entrepreneurship & & \\
\hline Access to credit & Pearson's corr. & 1 & 0.58787 & & \\
\hline Youth entrepreneurship & Sig. & -- & $6.35 \mathrm{E}-04$ & & & \\
\hline Youth entrepreneurship & Pearson's corr. & 0.58787 & 1 & & & \\
\hline
\end{tabular}

The correlation coefficient obtained was 0.58787 showing a moderate positive correlation between access to credit from government agencies and development of youth entrepreneurship. At 0.05, the significant value is $6.35 \mathrm{E}-04$ (or 0.000635 ) which shows that there is an overwhelming evidence that the relationship exists between youth entrepreneurship development and access to credit by the youth entrepreneurs from government agencies with a $95 \%$ confidence. The study, therefore, rejects the null hypothesis (there is no relationship) and accepts the alternative hypothesis (there is a relationship). This result is consistent with the findings by Musera (2015) in the literature (see page 4) showing the existence of a relationship between the financial support services and the success of youth enterprises.

\section{Conclusions}

This study investigated factors that affect youth entrepreneurship development in Kibera district in Kenya. These factors were the national youth policy on youth in the promotion and development of entrepreneurship, and access to credit. The correlation coefficient obtained was 0.5 and showed a moderate positive correlation between the National Youth Policy and development of youth entrepreneurship. The overwhelming evidence demonstrates the high degree of the NYP's influence on Youth Entrepreneurial Development, and equally so the high degree of influence of credit on youth entrepreneurship development. However, based on the results of hypothesis 2, it can be deduced that access to credit has a positive influence on the growth and success of youth enterprises. The positive relationship is an indication that the Kenyan government is, indeed, supporting youth entrepreneurship in Kibera, though the effectiveness of these support programs has been challenged, as many of the youth population remains unemployed and poor. This can be attributed to either unwillingness of the youths to take up the opportunities or other factors not considered in this study such as poor communication channel between the government agencies and the youths, or long bureaucracies in terms of accessing services such as registration of the business enterprises.

\section{Study limitation}

The study was conducted in the Kibera district and findings may not be generalized to the whole of Kenya, as the youth in Kenya may be heterogeneous due to geography.

\section{Recommendations}

- Financial assistance programs should be offered as a package that includes business skills training, mentoring, counselling, etc. This would not only ensure that young entrepreneurs get the finance they need to start and grow their 
business, but also would ensure that they also develop the necessary skills and knowledge that would enable them to run successful businesses.

- Further studies on factors affecting youth entrepreneurship development in other parts of Kenya should be conducted. These factors are, but not limited to, poor communication channel between the government agencies and the youths, student drop out from schools in both primary and secondary level despite provision of free education, high cost of higher level education and long bureaucracies in terms accessing services such as registration of the business enterprises.

\section{Policy implications}

It is hoped that the government of Kenya will take note of this study and, as a result, some inputs into the policies aimed at youth entrepreneurship will be drawn. This study is of the view that financial assistance programs in Kenya should be offered as a package that includes business skills training, mentoring, counselling, etc. and this be gazetted. This would not only ensure that young entrepreneurs get the finance they need to start and grow their business, but also would ensure that they also develop the necessary skills and knowledge that would enable them to run successful businesses.

\section{References}

1. African Economic Outlook. (2016). Youth Unemployment. Available at: http://www.africaneconomicoutlook.org/en/theme/developing-technical-vocational-skills-in-africa/tvsd-in-specificcontexts/youth-unemployment. Accessed on 2016-03-015.

2. Chigunta, F., Schnurr, J., James-Wilson, D. and Torres, V. (2005). Being "real" about youth entrepreneurship in Eastern and Southern Africa: Implications for adults, institutions and sector structures, ILO SEED Working Paper, 72, pp. 1-93. Available at: www.ilo.org/publns. Accessed on 19 August 2013.

3. Chiloane-Tsoka, G.E. and Mmako, N.M. (2014). Effects of migration and immigration on SMMEs: the case study of Diepsloot informal settlement, South Africa, Problems and Perspectives in Management, 12 (4), pp. 377-383.

4. Chitukutuku, E. (2014). Things youth in Africa consider important or valuable and how they inform youth participation in electoral and governance processes: Discussion paper for the 2014 Mandela Institute for Development Studies (MINDS) Annual youth dialogue in elections and governance. July 2014.

5. Crosson, C. (2005). Youth information networks in Kibera, Nairobi, Kenya 2004-2005 Hart Fellow; Duke University.

6. Gachugia, T.M., Mulu-Mutuku, M. and Odero-Waga, D. (2014). Role of youth enterprise development fund in curbing youth unemployment in kenya, European Journal of Social Sciences, Arts and Humanities, 2 (2), pp. 1-11.

7. Herrington, M., Kew, J. and Kew, P. (2010). Global Entrepreneurship Monitor: 2010 South African Report. Cape Town: University of Cape Town Graduate School of Business.

8. Herrington, M., Kew, J., Simrie, M. and Turton, N. (2011). Global Entrepreneurship Monitor: 2011 South Africa Report. Cape Town: University of Cape Town Graduate School of Business.

9. Kaburi, S.N., Mobegi, V.O., Kombo, A., Omari, A. and Sewe, T. (2012). Entrepreneurship Challenges in Developing Economies: a case of Kenyan Economy, International Journal of Arts and Commerce, 1 (4), pp. 264-274.

10. Kamau, E.N., Wanyoike, D. and Mwangi, B. (2014). Access to Credit Facilities as A Major Factor Hindering Access to Public Procurement Contracts By Youth Entrepreneurs in Government Ministries in OLKalou SubCounty, Kenya, International Journal of Science and Research (IJSR), pp. 2319-7064.

11. Kanyari, J.W. and Namusonge, G.S. (2013). Factors that Influence the Kenyan Youth Entrepreneurs Towards the Youth Enterprise Development Fund: A Case Study Of Gatundu South District, Kenya, International Journal of Education and Research, 1 (5), pp. 1-22.

12. Kenya National Youth Policy. (2007). Ministry of Home Affairs, Heritage and Sports. Available at: http://www.africanchildforum.org/clr/policy\%20per\%20country/kenya/kenya_youth_2007_en.

13. Sagwe Jackline, Gicharu Samuel, Mahea Timothy. (2011). Kenya Women Enterprise Fund Beneficiaries using the TRISTART Business Evaluation Tool. Kenya Institute of Management publication.

14. Kilele, A.K.M. (2008). Kenya National Bureau of Statistics (KNBS). Kenya facts and figures 2008. Available at: http://www.knbs.or.ke/index.php?option=com_phocadownload\&view=category\&id=20\&Itemid=1107. Accessed on 2015-10-01.

15. Kimando, L.N. and Njogu, G.W. (2012). An Investigation on University Students Habits towards Entrepreneurial in Kenya: A Case Study of the Kenyatta University Students, International Journal of Business and Commerce, 1 (9), pp. 199-222.

16. KVDA. (2015). Empowering the community for a healthy and gender sensitive approach to social participation. Western Kenya: VIHIGA COUNTY.

17. Llisteri, J.J., Kantis, H., Angelilli, P. and Tejerina, L. (2006). Is Youth Entrepreneurship a Necessity or an Opportunity? A first Exploration of Household and Enterprise Survey in Latin America, Sustainable Development Department Technical Paper Series, Inter-America Development Bank, Washington DC.

18. Maina, S.W. (2012). Factors influencing the development of youth entrepreneurship in Ongata Rongai Township. Master of Arts Thesis. Nairobi: University of Nairobi. Available at: http://erepository.uonbi.ac.ke:8080/xmlui/handle/123456789/10886. Accessed on 25 September 2013. 
19. Maxwell, J.R. (2002). Recommendations for connecting West African youth to entrepreneurship and small business through a multiple level strategy. Paper presented at United States Association for Small Business and Entrepreneurship International Conference, Reno, Nevada U.S.A., January 17-20, 2002.

20. Moraa new hope foundation. (2015). Challenges facing Kenyan youths. Available at: http://www.moraafoundation.org/challenges-facing-kenyan-youths. Accessed on 2014-07-17.

21. Mureithi, M. (2010). Barriers and Facilitators of Youth Entrepreneurship in the Tourism Sector in South Africa. Master of Business Administration Thesis, University of Pretoria, Pretoria.

22. Murimi, B.M. (2014). Factors affecting the success of start-up of youth enterprises in Nairobi County, Kenya. Unpublished Master of Art dissertation. Kenya: University of Nairobi.

23. Musera, A.D. (2015). Factors affecting the success of kenya youth enterprise development funded projects in kenya: a survey of langata constituency, Nairobi county. Unpublished Master of Business Administration report. Kenya: United States International University Africa.

24. Mwangi, I.W. and Shem, A.O. (2012). Social capital and access to credit in Kenya, American Journal of Social and Management Sciences, 3 (1), pp. 8-16.

25. Office of the President and Ministry of State for Youth Affairs. (2007). Strategic Plan 2007-2012. March 2007.

26. Okirigiti, C.A. and Rafey, M.A. (2015). Challenges Facing Youth Entrepreneurs in Slums in Kenya: A case of Kisumu Ndogo Slums in Eldoret Municipality Kenya, European Open Business \& Management Journal, 1 (1), pp. 1-10.

27. Omondi, P. (2013). Youth Enterprise: Inhibiting Factors and Opportunities. Available at: http://ems.uonbi.ac.ke/node/1345. Accessed on 03 March 2013.

28. Rori, A., Bunei, J. and Mwenzwa, E. (2011). Revitalizing youth entrepreneurship in Kenya: A Deliberate Training Curriculum, International Journal of current research, 3 (10), pp. 121-125.

29. Sagwe, J., Gicharu, S. and Mahea, T. (2011). A Study on Youth and Women Entrepreneurs' Preparedness in Kenya: A Case Study of the Kenya Youth Enterprise Development Fund and Kenya Women Enterprise Fund Beneficiaries using the TRISTART Business Evaluation Tool. Kenya Institute of Management.

30. Schoof, U. (2006). Stimulating Youth Entrepreneurship: Barriers and incentives to enterprise start-ups by young people, International Labor Office, Geneva, Switzerland.

31. Simiyu, J. and Sambu, L. (2012). Nature and Type of Government and NGO Interventions in Curbing Unemployment and Underemployment of Urban Youth in Kenya, Journal of Emerging Trends in Educational Research and Policy Studies, 3 (5), pp. 730-736.

32. United Nations Educational, Science and Cultural Organization (UNESCO). (2010). UNESCO SHS Strategy on African Youth: Towards and Enabling Policy Environment for Youth Development and Civic Engagement in Africa (2009-2013). Executive Board Report 184th session in Paris.

33. Youth Business International. (2011). Youth entrepreneurship: Closing the gap. Available at: http://www.youthbusiness.org. Accessed on 2 February 2014.

34. Valerio, A., Parton, B. and Robb, A. (2014). Entrepreneurship Education and Training Programs around the World: Dimensions for Success. World Bank. Washington DC. 